\title{
Reliability and Validity of the Korean Version VISA-P Questionnaire for Patellar Tendinopathy in Adolescent Elite Volleyball Athletes
}

\author{
Byung-Hyun Park, MD, Jeong-Hwan Seo, MD, Myoung-Hwan Ko, MD, Sung-Hee Park, MD
}

Department of Physical Medicine and Rehabilitation, Institute for Medical Sciences, Chonbuk National University Medical School and Research Institute of Clinical Medicine, Chonbuk National University Hospital, Jeonju, Korea

\begin{abstract}
Objective To translate the English Victorian Institute of Sport Assessment for patellar tendinopathy (VISA-P) questionnaire into a Korean version and to determine the reliability and validity of the Korean version.

Methods The English VISA-P questionnaire was translated into Korean according to the internationally recommended guidelines. Then, 28 adolescent elite volleyball athletes (average age, 16 years; range, 14 to 19 years) were asked to complete the questionnaire three times (before examination, after examination, and 1 week later) for reliability. They were evaluated through a physical examination and ultrasonography to diagnosis patellar tendinopathy.

Results The internal consistency of the VISA-P questionnaire by Cronbach's alpha was 0.80 for the first, 0.78 for the second, and 0.79 for the third assessment. The intraclass correlation coefficient (ICC) between the first and second assessments was 0.97 . The ICC between the second and third assessments was 0.96. The mean VISA-P scores were $67.6 \pm 15.7$ for the patellar tendinopathy group $(n=23)$ and $92.6 \pm 8.6$ for the normal group $(n=5)$. There were significantly lower VISA-P scores in the patellar tendinopathy group compared to the normal group.

Conclusion The translated Korean version VISA-P questionnaire has good internal consistency, test-retest reliability and validity. In addition, this study indicated that most adolescent elite volleyball athletes had patellar tendon problems. Therefore, the Korean version VISA-P is a useful self-administered outcome score of athletes with patellar tendinopathy.
\end{abstract}

Keywords Patellar tendon, Tendinopathy, Athletes, Reliability, Validity

Received March 8, 2013; Accepted July 18, 2013

Corresponding author: Jeong-Hwan Seo

Department of Physical Medicine and Rehabilitation, Chonbuk National University Medical School, 567 Baekje-daero, Deokjin-gu, Jeonju 561756 , Korea

Tel: +82-63-250-1797, Fax: +82-63-254-4145, E-mail: vivaseo@jbnu.ac.kr

() This is an open-access article distributed under the terms of the Creative Commons Attribution Non-Commercial License (http://creativecommons. org/licenses/by-nc/3.0) which permits unrestricted noncommercial use, distribution, and reproduction in any medium, provided the original work is properly cited.

Copyright $\odot 2013$ by Korean Academy of Rehabilitation Medicine

\section{INTRODUCTION}

Patellar tendinopathy, also known as jumper's knee, is a common disorder in jumping and running athletes. As an insertional tendinopathy most commonly affecting the origin of the patellar tendon at the inferior pole of the patella, this overuse injury is known to be caused by continuous and repetitive stress on the knee extensor apparatus [1-4]. The prevalence is particularly high in 
sports where jumping is essential, such as basketball and volleyball. The reported prevalence among elite volleyball players is $40 \%-50 \%[5,6]$.

Victorian Institute of Sport Assessment for patellar tendinopathy (VISA-P) questionnaire was developed by the VISA Tendon Study Group to quantify the degree of symptoms caused by patellar tendinopathy [7], and has been proved to have high reliability and validity for the assessment of the degree of improvement from patellar tendinopathy $[8,9]$. It has been also translated for use in Sweden, Italy, and Germany [10-12].

The objectives of this study were to translate the VISA$P$ questionnaire into Korean language and to determine the reliability and validity of the Korean version among adolescent elite volleyball players.

\section{MATERIALS AND METHODS}

The questionnaire was administered to 28 elite volleyball players who are currently attending middle/high schools. Physical examinations and ultrasonography were performed for the diagnosis of patellar tendinopathy. The height and body weight were measured before the physical examinations, and the overall duration of training, training time per week, and past history of knee injury were investigated. Patellar tendinopathy was diagnosed when there was pain in the patellar tendon area during or after an activity that might load the patellar tendon based on past history, and when there is tenderness on the patellar tendon area based on physical examination $[13,14]$. Athletes were excluded if they had a history of knee surgery or an injury to the ligament or cartilage. Participants who were diagnosed as patellar tendinopathy were subdivided based on their severity of clinical symptoms according to the classification described by Roels et al. [15]. The degree of knee pain was evaluated by a visual analogue scale (VAS), and the participants were evaluated as to whether squatting induced pain. For ultrasonography, z.one (Zonare Medical System, Mountain View, CA, USA) ultrasound device with a high-resolution linear probe at $12 \mathrm{MHz}$ frequency was used while the knees were flexed at $30^{\circ}$ in order to determine whether the patellar tendon had any structural change, which is defined as the presence of increased tendon thickness, loss of fibrillar pattern, and presence of a hypoechoic lesion $[16,17]$.

The VISA-P questionnaire is composed of a total of 8 questions: 6 among them assess pain induced during daily life activity or simple tests of function, scored on an inversed VAS from 0 to 10 . The remaining 2 questions assess the ability to undertake physical activity. The maximal score is 100 , representing no knee pain and perfectly performing the activity [7]. In question no. 8, the VISA group later modified the time unit of how long one can train/practice. We translated the modified version of the VISA-P questionnaire.

The VISA Tendon Study Group consented on the translation of VISA-P questionnaire into the Korean language (Jill Cook, personal correspondence, 2011). Two rehabilitation physicians, who are proficient in the English language, first translated the questionnaire into the Korean language, and then an American who is proficient in the Korean language performed a back-translation. The back-translated version was compared with the original questionnaire in order to confirm if the translation was accurate without change of meaning; if there was a disagreement in the meaning between the original and the translated questionnaires, the Korean version was corrected so that the original meaning could be delivered as it is. The two rehabilitation physicians reviewed the questionnaire for the last time and the Korean version VISA-P questionnaire was completed. A preliminary survey was performed in 5 normal adults; however, some of them misunderstood the term lunge in question no. 4 and squatting in question no. 5 . To help with the understanding, reference pictures were inserted and the Korean version VISA-P questionnaire was finalized (Appendix 1).

To determine the reliability, the questionnaire was administered a total of 3 times (immediately before and after the tests and one week after the tests) to the athletes. Inter-tester and test-retest reliabilities were measured; Cronbach's alpha coefficient was used to assess the former, and intraclass correlation coefficient (ICC) was used for the latter. For the assessment of validity, VISA-P scores were compared between the patellar tendinopathy group and the healthy control group using the Mann-Whitney U test. The number of subjects was determined according to the method by Walter et al. [18]; the required number of subjects was 22 when $\alpha=0.05, \beta=0.2, \rho_{0}=0.5, \rho_{1}=0.8$, and $\mathrm{n}=2$. Considering a $20 \%$ dropout rate, the minimum required number of subjects was 28. SPSS ver. 18.0 (SPSS Inc., Chicago, IL, USA) was used for statistical analysis. 


\section{RESULTS}

\section{General characteristics}

A total of 28 athletes participated in the study, and the number of dropout was 0 . The participants consisted of 13 male and 15 female athletes; their mean age was 15.9 years, height was $172.4 \mathrm{~cm}$, and weight was $66.8 \mathrm{~kg}$ (Table 1). Patellar tendinopathy was diagnosed in 23 out of the 28 athletes based on their history and physical examinations. According to Roels et al's classification [15], 5 patients were in stage 1,17 in stage 2,1 in stage 3 , and 0 in stage 4 . Squatting induced patellar tendinopathy symptoms in 18 out of 23 patients in the patellar tendinopathy group, but not in any of the 5 subjects in the healthy control group (Table 2). The location of the lesion was on the left knee in 8 patients, on the right knee in 8 patients, and bilateral in 7 patients.

Table 1. General characteristics of subjects

\begin{tabular}{lc}
\hline \multicolumn{1}{c}{ Characteristic } & Value \\
\hline Age $(\mathrm{yr})$ & $15.9 \pm 1.9$ \\
Gender (male:female) & $13: 15$ \\
Height $(\mathrm{cm})$ & $172.4 \pm 6.2$ \\
Weight $(\mathrm{kg})$ & $66.8 \pm 9.1$ \\
Body mass index $\left(\mathrm{kg} / \mathrm{m}^{2}\right)$ & $22.4 \pm 2.3$ \\
\hline Sport hours per week & $32.0 \pm 10.4$ \\
\hline Duration of sport activity $(\mathrm{yr})$ & $48.3 \pm 20.9$ \\
\hline
\end{tabular}

Values are presented as mean \pm standard deviation or number

\section{Ultrasonographic findings}

The patellar tendon showed a structural change in 19 out of 23 patients in the patellar tendinopathy group; 5 of them had Osgood-Schlatter disease and 1 had SindingLarsen-Johansson disease. In the healthy control group, 1 out of 5 subjects had structural change of the patellar tendon with Osgood-Schlatter disease (Table 3). The sensitivity and specificity of ultrasonography was $82.6 \%$ and $80.0 \%$, respectively, for the diagnosis of patellar tendinopathy.

\section{Reliability analysis}

Cronbach's alpha coefficients were $0.80,0.78$, and 0.79 , respectively, for the questionnaire administration conducted three times (Table 4). Short-term ICC reliability (immediately before and after the test) was 0.97 , and long-term ICC reliability (1 week after the test) was also high at 0.96 (Table 5).

\section{Validity analysis}

The mean VISA-P score in the patellar tendinopathy group was $67.6 \pm 15.7$, compared to $92.6 \pm 8.6$ in the healthy control group, showing a statistically significant difference $(\mathrm{p}<0.05)$. In addition, the mean VAS score in the patellar tendinopathy group was $5.9 \pm 1.9$ compared to 0 in the healthy control group, also showing a statistically significant difference $(\mathrm{p}<0.05)$. The mean VISA-P scores according to the classification of clinical symptom severity were $86.2 \pm 8.4$ (stage 1), $63.9 \pm 11.9$ (stage 2 ) and 37.0 (stage 3 ), and the mean VAS scores were $5.4 \pm 2.6,6.1 \pm 1.7$,

Table 2. Clinical findings between normal and patellar tendinopathy groups

\begin{tabular}{lcccc} 
& \multirow{2}{*}{ Normal group $(\mathbf{n}=\mathbf{5})$} & \multicolumn{3}{c}{ Patellar tendinopathy group } \\
\cline { 2 - 5 } & & Stage $\mathbf{1}(\mathbf{n}=\mathbf{5})$ & Stage $\mathbf{2}(\mathbf{n}=\mathbf{1 7})$ & Stage 3 $(\mathbf{n}=\mathbf{1})$ \\
\hline VAS & 0 & $5.4 \pm 2.6$ & $6.1 \pm 1.7$ & 7.0 \\
VISA-P score & $92.6 \pm 8.6$ & $86.2 \pm 8.4$ & $63.9 \pm 11.9$ & 37.0 \\
Provocation test $(+)$ & 0 & 5 & 12 & 1 \\
\hline
\end{tabular}

Values are presented as mean \pm standard deviation or number.

VAS, visual analogue scale; VISA-P, Victorian Institute of Sport Assessment for patellar tendinopathy.

Table 3. Ultrasonographic (US) findings between normal and patellar tendinopathy groups

\begin{tabular}{lcc}
\hline & Normal $(\mathbf{n}=\mathbf{5})$ & Patellar tendinopathy $(\mathbf{n}=\mathbf{2 3})$ \\
\hline Normal US finding & 4 & 4 \\
Abnormal US finding $\left(\mathrm{Osgood}^{\mathrm{a})}\right)$ & $1(1)$ & $19(6)$ \\
\hline
\end{tabular}

${ }^{\mathrm{a})}$ Osgood-Schlatter and Sinding-Larsen-Johansson diseases. 
Table 4. Internal consistency of the Korean version VISAP questionnaire by Cronbach's alpha

\begin{tabular}{|cccc|}
\hline Sub-item of VISA-P & Test 1 & Test 2 & Test 3 \\
\hline Q1 & 0.75 & 0.73 & 0.73 \\
Q2 & 0.77 & 0.73 & 0.75 \\
Q3 & 0.79 & 0.76 & 0.77 \\
Q4 & 0.78 & 0.74 & 0.76 \\
Q5 & 0.75 & 0.71 & 0.74 \\
\hline Q6 & 0.75 & 0.70 & 0.73 \\
\hline Q7 & 0.81 & 0.80 & 0.81 \\
\hline Q8 & 0.85 & 0.87 & 0.85 \\
\hline Total & 0.80 & 0.78 & 0.79 \\
\hline
\end{tabular}

VISA-P, Victorian Institute of Sport Assessment for patellar tendinopathy.

and 7.0, respectively (Table 2).

\section{DISCUSSION}

In this study, test-retest reliabilities of VISA-P questionnaire were 0.97 and 0.96 , respectively, for 2 -hour and 1 -week intervals, which are similar to 0.96 reported by Visentini et al. [7] in the original version VISA-P study and 0.97 reported by Frohm et al. [10] in the Swedish version VISA-P study. The inter-test reliabilities were 0.80 , 0.78 , and 0.79 for survey which was conducted 3 times. Further, the results were also similar to 0.83 and 0.82 reported by Frohm et al. [10] in the Swedish version VISA-P study, and 0.73 and 0.71 reported by Zwerver et al. [12] in the German version VISA-P study. Thus, the Korean version VISA-P questionnaire in this study appears to have high reliability as those of the original and other versions of VISA-P questionnaires.

In terms of validity, the mean VISA-P score was $67.6 \pm 15.7$ in the patellar tendinopathy group, which is a statistically significant reduction compared to $92.6 \pm 8.6$ in the healthy control group. When compared to the VISA-P scores in the previous studies, our mean VISA-P score in the patellar tendinopathy group tends to be higher than 55 reported by Visentini et al. [7] in the original VISAP study, 48 and 52 reported by Frohm et al. [10] in the Swedish version VISA-P study, and 58 reported by Zwerver et al. [12] in the German version VISA-P study. Considering that patellar tendinopathy is an injury from repetitive overuse [2-4], such difference might be explained by the fact that our study was performed among adolescent
Table 5. Test-retest reliability of the Korean Version VISA$\mathrm{P}$ questionnaire by intraclass correlation coefficient

\begin{tabular}{ccc}
\hline $\begin{array}{c}\text { Sub-item } \\
\text { of VISA-P }\end{array}$ & Short-term interval & $\begin{array}{c}\text { Long-term } \\
\text { interval }\end{array}$ \\
\hline Q1 & 0.99 & 0.96 \\
\hline Q2 & 0.99 & 0.98 \\
\hline Q3 & 0.88 & 0.88 \\
\hline Q4 & 0.91 & 0.89 \\
\hline Q5 & 0.95 & 0.89 \\
\hline Q6 & 0.94 & 0.96 \\
\hline Q7 & 0.79 & 0.71 \\
\hline Q8 & 0.87 & 0.94 \\
\hline Total & 0.97 & 0.96 \\
\hline
\end{tabular}

VISA-P, Victorian Institute of Sport Assessment for patellar tendinopathy.

elite athletes, whose overall duration of training was relatively shorter than that of adult athletes included in the previous studies. The healthy control group in our study is composed of other adolescent elite volleyball players, who can be categorized as a high risk group of patellar tendinopathy. Compared to the high risk groups in the previous studies, the mean VISA-P score in our healthy control group is similar to 93 reported by Visentini et al. [7] in the original VISA-P study, 79 and 80 reported by Frohm et al. [10] in the Swedish version VISA-P study, and 89 reported by Zwerver et al. [12] in the German version VISA-P study.

In this study, the degree of clinical symptoms of patellar tendinopathy was divided using Roels et al.'s classification [15]: stage 1 is the presence of pain after activity, stage 2 is the presence of pain at the beginning of activity, disappearing after warming up and reappearing after completion of activity, stage 3 is the presence of pain remaining during and after activity and the patient is unable to participate in sports, and stage 4 is the presence of a complete rupture of the patellar tendon. Stages 1 and 2 is known to result in good outcome after an appropriate conservative treatment, whereas stage 3 needs prolonged rest and reduced frequency of training and practice [19]. Our finding, that most adolescent elite volleyball players had stage 1 or stage 2 clinical symptoms, suggest the importance of proper diagnosis and treatment for knee pain during adolescence in these athletes.

Patellar tendinopathy, or jumper's knee, may develop after a variety of sports that require repetitive jumping 
and running, and is particularly frequent among volleyball or basketball players $[6,14,16]$. The incidence of patellar tendinopathy among adult male volleyball players was reported as $40 \%$ by Ferretti [5] and $50 \%$ by Lian et al. [13]. The incidence among adolescent elite volleyball players was reported as $21 \%$ by Gisslen et al. [16], but has not been reported in Korea. In our study, the incidence among 28 volleyball players attending middle/high schools was as high as $82.1 \%(n=23)$. Moreover, the incidence of Osgood-Schlatter disease and Sinding-LarsenJohansson disease, two frequent diseases in adolescents, was $25 \%$. These two diseases were included in the patellar tendinopathy group, because both of these conditions is accompanied by an inflammatory change of the patellar tendon along with other findings that can be observed with patellar tendinopathy, such as patellar tendon pain on physical examination and increased thickness of patellar tendon on ultrasonography $[20,21]$. Thus, our findings imply the necessity of continuous interest and studies on knee pain among adolescent athletes in the future.

One limitation of this study is that the reliability and validity of the Korean version VISA-P questionnaire was analyzed only in adolescent athletes. Further studies are needed involving adult athletes in the future. Patellar tendinopathy is common among other athletes, such as basketball players, as well. Our study included only volleyball players and calls for additional studies involving other sports.

In conclusion, the Korean version VISA-P questionnaire was found to have satisfactory reliability and validity. Thus, it may be useful in assessing the treatment of patellar tendinopathy in Korean athletes in the future.

\section{CONFLICT OF INTEREST}

No potential conflict of interest relevant to this article was reported.

\section{REFERENCES}

1. Blazina ME, Kerlan RK, Jobe FW, Carter VS, Carlson GJ. Jumper's knee. Orthop Clin North Am 1973;4:66578.

2. Khan KM, Maffulli N, Coleman BD, Cook JL, Taunton JE. Patellar tendinopathy: some aspects of basic science and clinical management. Br J Sports Med
1998;32:346-55.

3. Fredberg U, Bolvig L. Jumper's knee: review of the literature. Scand J Med Sci Sports 1999;9:66-73.

4. Peers KH, Lysens RJ. Patellar tendinopathy in athletes: current diagnostic and therapeutic recommendations. Sports Med 2005;35:71-87.

5. Ferretti A. Epidemiology of jumper's knee. Sports Med 1986;3:289-95.

6. Lian OB, Engebretsen L, Bahr R. Prevalence of jumper's knee among elite athletes from different sports: a cross-sectional study. Am J Sports Med 2005;33:561-7.

7. Visentini PJ, Khan KM, Cook JL, Kiss ZS, Harcourt PR, Wark JD. The VISA score: an index of severity of symptoms in patients with jumper's knee (patellar tendinosis). Victorian Institute of Sport Tendon Study Group. J Sci Med Sport 1998;1:22-8.

8. Khan KM, Visentini PJ, Kiss ZS, Desmond PM, Coleman BD, Cook JL, et al. Correlation of ultrasound and magnetic resonance imaging with clinical outcome after patellar tenotomy: prospective and retrospective studies. Victorian Institute of Sport Tendon Study Group. Clin J Sport Med 1999;9:129-37.

9. Cook JL, Khan KM, Purdam CR. Conservative treatment of patellar tendinopathy. Phys Ther Sport 2001;2:54-65.

10. Frohm A, Saartok T, Edman G, Renstrom P. Psychometric properties of a Swedish translation of the VISAP outcome score for patellar tendinopathy. BMC Musculoskelet Disord 2004;5:49.

11. Maffulli N, Longo UG, Testa V, Oliva F, Capasso G, Denaro V. VISA-P score for patellar tendinopathy in males: adaptation to Italian. Disabil Rehabil 2008;30:1621-4.

12. Zwerver J, Kramer T, van den Akker-Scheek I. Validity and reliability of the Dutch translation of the VISA-P questionnaire for patellar tendinopathy. BMC Musculoskelet Disord 2009;10:102.

13. Lian O, Holen KJ, Engebretsen L, Bahr R. Relationship between symptoms of jumper's knee and the ultrasound characteristics of the patellar tendon among high level male volleyball players. Scand J Med Sci Sports 1996;6:291-6.

14. Seo KH, Seo KM, Kim SW, Kim BK, Song IS. Study on jumper's knee: symptom and diagnostic method by using MRI and ultrasonography in basketball players. J Korean Acad Rehabil Med 1998;22:1312-7. 
15. Roels J, Martens M, Mulier JC, Burssens A. Patellar tendinitis (jumper's knee). Am J Sports Med 1978;6:362-8.

16. Gisslen K, Gyulai C, Soderman K, Alfredson H. High prevalence of jumper's knee and sonographic changes in Swedish elite junior volleyball players compared to matched controls. Br J Sports Med 2005;39:298-301.

17. Jonsson $\mathrm{P}$, Alfredson $\mathrm{H}$. Superior results with eccentric compared to concentric quadriceps training in patients with jumper's knee: a prospective randomised study. Br J Sports Med 2005;39:847-50.

18. Walter SD, Eliasziw M, Donner A. Sample size and optimal designs for reliability studies. Stat Med 1998;17:101-10.

19. Ferretti A, Puddu G, Mariani PP, Neri M. The natural history of jumper's knee: patellar or quadriceps tendonitis. Int Orthop 1985;8:239-42.

20. De Flaviis L, Nessi R, Scaglione P, Balconi G, Albisetti W, Derchi LE. Ultrasonic diagnosis of OsgoodSchlatter and Sinding-Larsen-Johansson diseases of the knee. Skeletal Radiol 1989;18:193-7.

21. Hirano A, Fukubayashi T, Ishii T, Ochiai N. Magnetic resonance imaging of Osgood-Schlatter disease: the course of the disease. Skeletal Radiol 2002;31:334-42. 


\section{Appendix 1.}

\section{한국어판 VISA-P 설문지}

이름:

날짜:

1. 통증 없이 몇 분간 앉아있을 수 있습니까?

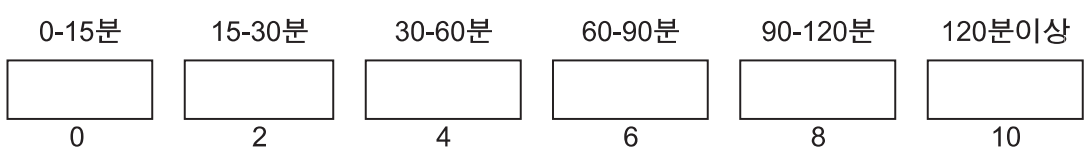

2. 평상시 계단을 내려갈 때 통증이 있습니까?

심한 통증/ 할수 없음

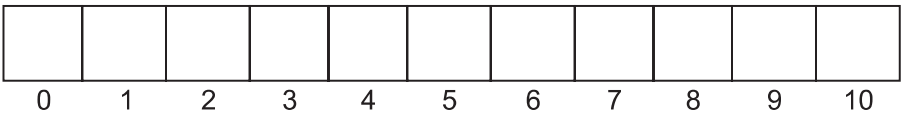

통증 없음

3. 체중 부하 없이 무릎을 완전히 폈을 때 무릎에 통증이 있습니까?

심한 통증/

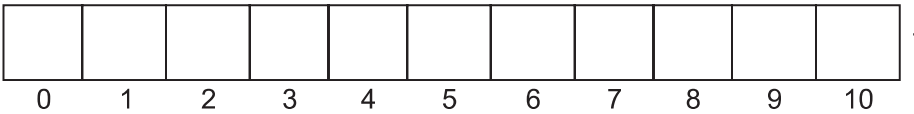

통증 없음

4. 런지(lunge)를 할 때 통증이 있습니까?

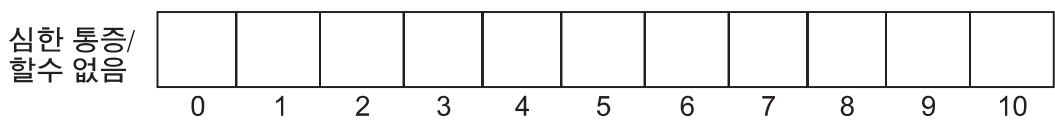

통증 없음

5. 스쿼팅(squatting)을 할 때 문제가 있습니까?

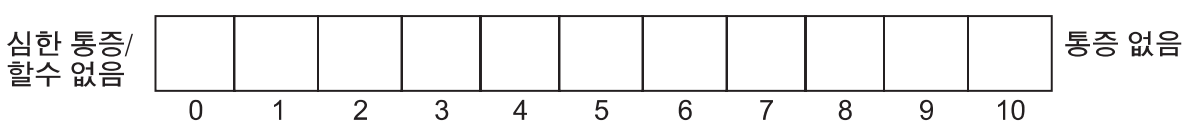

※참고그림: 런지(lunge) 동작

스쿼팅(squatting) 동작
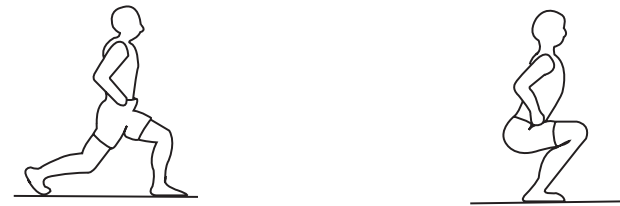
6. 한발로 10 번 뛰는 동안 또는 직후에 통증이 있습니까?

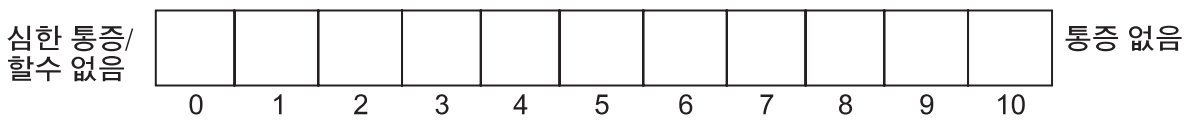

7. 현재 정상적인 훈련이나 활동을 수행하고 있습니까?

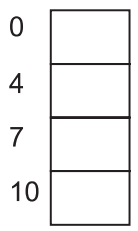

전혀 하지 못함.

조절된 훈련 또는 활동

완전한 훈련 또는 경기를 수행하나 증상이 시작되면 같은 수준은 아님.

증상이 시작되어도 같은 수준으로 경기를 수행.

8. 이번 질문은 세 가지로, 한 가지에만 답하여 주십시오.

- 활동 또는 운동을 하는 동안 통증이 없다면 $\rightarrow$ 질문 8a에만 답하여 주십시오.

- 활동 또는 운동을 하는 동안 통증이 있지만, 훈련을 중단할 정도는 아닌 경우 $\rightarrow$ 질문 $8 \mathrm{~b}$ 에만 답하여 주십시오.

- 활동 또는 운동을 하는 동안 통증으로 인하여 중단하는 경우 $\rightarrow$ 질문 $8 \mathrm{c}$ 에만 답하여 주십시오.

8a. 운동을 하는 동안 통증이 없다면, 얼마나 오랫동안 훈련할 수 있습니까?

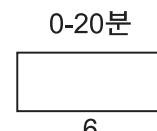

6

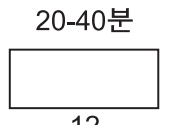

12

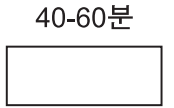

18

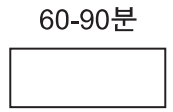

24

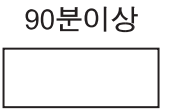

30

$8 \mathrm{~b}$. 운동을 하는 동안 약간의 통증이 있지만, 훈련을 중단할 정도는 아니라면, 얼마나 오랫동안 훈련할 수 있습니까?
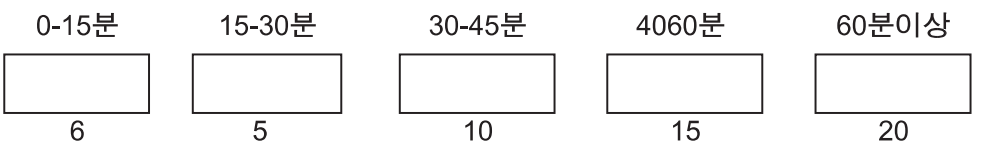

8c. 운동을 하지 못할 정도의 통증이 있다면, 얼마나 오랫동안 훈련할 수 있습니까?
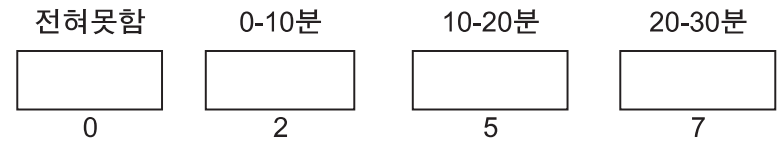

30 분이상 